\title{
Cervical Spinal Cord
}

National Cancer Institute

\section{Source}

National Cancer Institute. Cervical Spinal Cord. NCI Thesaurus. Code C12892.

The portion of the spinal cord located in the cervical region. 